\title{
IMPROVEMENT OF THE CHARACTERISTIC OF POL YETHERSULFONE MEMBRANE BY BLENDING WITH BRIJ OF DIFFERENT MOLECULAR WEIGHTS
}

\author{
M. Y. Wahab ${ }^{1}$, S. Muchtar ${ }^{1}$, S. Mulyati ${ }^{2,3}$, M. Riza $^{2}$, N. Arahman ${ }^{2,3, *}$ \\ and M. A. A. Baig ${ }^{4}$ \\ ${ }^{1}$ Doctoral School of Engineering Science, Syiah Kuala University, 23111, \\ Banda Aceh, Indonesia \\ ${ }^{2}$ Department of Chemical Engineering, Syiah Kuala University, 23111, Banda Aceh, Indonesia \\ ${ }^{3}$ Graduate School of Environmental Management, Universitas Syiah Kuala, \\ Banda Aceh, Indonesia \\ ${ }^{4}$ Department of Mechanical, CMR Technical Campus Kandlakoya, \\ Medchal Road, Hyderabad-501401, India \\ *E-mail: nasrular@unsyiah.ac.id
}

\begin{abstract}
In the fabrication of membrane via common phase inversion technique, the morphology and other basic characteristics of the resulted membrane are greatly influenced by the composition of polymer and solvent. The presence of the second chemical in the polymer solution might also change the surface property of the membrane. In this work, PES membrane in flat-sheet form is fabricated by means of NIPS method by blending three kinds of Brij with different molecular weights (Brij 58, 98, and 35) into polymer solution to enhance the hydrophilicity degree of the membrane. The effect of the additive on the hydrophilic property of the membrane is studied through the measurement of surface water contact angle. In addition, the filtration and separation performances of the membranes are examined by determining water flux and rejection in filtration experiment against humic acid. It is concluded that the optimum pure water permeability can be required by using Brij with higher molecular weight and lower the concentration. The addition of additive showed membrane modified with Brij35 has higher hydrophilicity property.
\end{abstract}

Keywords: Polyethersulfone (PES), Brij, Non-ionic Surfactant, Hydrophilic Membrane, Ultra Filtration, Green Technology

(C) RASĀYAN. All rights reserved

\section{INTRODUCTION}

Since its introduction half a century ago, membrane technology has attracted a lot of interest from researchers. Its application in producing water in large quantities is more advantageous compared to conventional processes. ${ }^{1}$ This is due to the relatively simple operations with low energy requirements and maintenance costs compared to conventional methods.

One of the polymeric materials commonly used as an ultrafiltration membrane is polyethersulfone (PES). This polymer is popular for having superior resistance to chemicals, outstanding stability even at higher operating temperature, and satisfactory mechanical strength, hence widely used in the manufacture of membranes for various applications. ${ }^{2}$ However, pure PES membrane has a hydrophobic nature, leading to a weak interaction with water but strong interaction with contaminant molecules, the main drawback in practical application. ${ }^{3}$ For this reason, various methods are used to improve membrane performance, among them the improvement of its hydrophilicity through the addition of hydrophilic component. ${ }^{4-7}$

The involvement of hydrophilic additive in membrane modification has been studied by a number of researchers in the past. ${ }^{8-11}$ It is reported to have successfully improved the characteristics of the membrane

Rasayan J. Chem., 12(3), 1135-1143(2019)

http://dx.doi.org/10.31788/RJC.2019.1235340

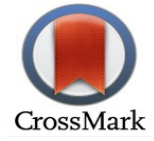


when it comes to porous properties and surface hydrophilicity, a very advantageous feature in filtration. ${ }^{12-}$

15 There are so many hydrophilic materials which may be used as membrane additive, including surfactants such as Tetronic $1307,{ }^{16}$ sodium dodecyl sulfate (SDS), ${ }^{17}$ Triton $\mathrm{x}-100,{ }^{18}$ and Tween $80 .{ }^{19,20}$ Surfactant is the most important material in a detergent group. It is comprised of a hydrophobic part attached to a hydrophilic functional group, and it is divided into: anionic, cationic, non-ionic and zwitterionic. $^{21}$ It was earlier established that its addition to the dope solution can improve the porosity of the membrane and increase pure water permeability. ${ }^{16}$ Brij is another type of surfactant which may possibly be used as a membrane additive. It has an outstanding performance as a pore-forming and flux promoting agent. It is an amphiphilic non-ionic surfactant possessing both hydrophilic and lipophilic parts with hydrophile-lipophile balance (HLB) value $>10$. HLB is a parameter which measures the surfactant affinity to water and commonly ranges from 0-20. A material with an HLB number of $>10$ indicates a higher affinity to water (hydrophilic) while the one with HLB number of $<10$ has a high affinity for oil (lipophilic). ${ }^{22}$

Despite its promising role in improving performance, the use of Brij as an additive in membrane fabrication is understudied. Evidently, it has only been reported in a few membrane modification-related works. For example, Omidvar ${ }^{23}$ studied the effects of Brij S100 on the separation ability of PES membrane for removal of amoxicillin in hospital waste. In another study, a similar investigation was carried out, though using Brij58. ${ }^{24}$ Both studies showed Brij had positive impacts on the membrane in terms of characteristics and performance. Our previous study researched the effect of Brij58 $8^{25}$ and Brij35 ${ }^{26}$ on the PES and PVDF membranes for water treatment application.

From the foregoing, there are various types of Brij, each denoted by specific numbers representing molecular weights. However, there is no documented study on different types of Brij. Besides, the effects of concentration have not studied deeply. The concentration along with molecular weights of the additive greatly influence the formation of membrane structure and performance since it causes changes in the thermodynamic and kinetic properties. Kim and $\mathrm{Lee}^{27}$ examined the influences of Polyethylene Glycol (PEG) molecular weights on the formation of PEI asymmetric membranes. from their results, PEG with low molecular weights, such as PEG200 and PEG400, hindered the formation of pores on PEI membranes, and the same results were reported on the PVDF membrane. ${ }^{28}$ According to Saljoughi et al., ${ }^{29}$ the addition of PEG with a low molecular weight in casting solution during the formation of cellulose acetate membrane may increase the permeability and stability to thermal or chemical of the product. In this reported work, similar work is carried out on PES membrane using Brij with different molecular weights (Brij35, $1199.558 \mathrm{~g} / \mathrm{mol}$; Brij98, $1149.56 \mathrm{~g} / \mathrm{mol}$; Brij58, $1124 \mathrm{~g} / \mathrm{mol}$ ) and concentrations (1, 3, 5, 7 , and $10 \mathrm{wt} \%$ ). The influences of additive Mws and concentrations were studied on the basis of chemical composition, porosity, hydrophilicity, mechanical strength, and filtration ability.

\section{Materials}

\section{EXPERIMENTAL}

Some of the materials used in preparation of membrane include: Polyethersulfone (PES, type Ultrason E6020P, BASF Co) as a base polymer, solvent used was dimethyl-formamide (DMF, WAKO Pure Chemical Industries, Ltd, Japan), and deionized (DI) water which acquired from Industry Research and Development Agency, and BARISTAND, Banda Aceh was used as a non-solvent. In addition, Brij of different molecular weights: Brij35 (1199.558 g/mol), Brij 98 (1149.56 g/mol), and Brij58 (1124 g/mol) were purchased from BASF Co and used as surfactant additives. Also, Humic Acid (HA, BASF Co) artificial sample as a water contaminant model was prepared at $10 \mathrm{ppm}$.

\section{Membrane Preparation}

The fabrication of membrane was carried out by means of a non-solvent induced phase separation (NIPS) method by dissolving $18 \mathrm{wt} \%$ of PES and a certain concentration of Brij in a DMF solvent. These components were mixed to homogeneity at room temperature. The detailed of the composition of each membrane component is given in Table 1 . The procedure was continued with the casting process of the 
polymer solution on the surface of a glass plate using an applicator with thickness adjusted at $200 \mu \mathrm{m}$. Phase separation process was completed by dipping the cast plate into a non-solvent bath.

Table-1: Composition Breakdown of the Membranes

\begin{tabular}{c|c|c|c|c}
\hline $\begin{array}{c}\text { Membrane } \\
\text { ID }\end{array}$ & $\begin{array}{c}\text { PES } \\
\text { (wt\%) }\end{array}$ & $\begin{array}{c}\text { DMF } \\
\text { (wt\%) }\end{array}$ & $\begin{array}{c}\text { Brij weight } \\
\text { ratio (wt\%) }\end{array}$ & $\begin{array}{c}\text { Brij } \\
\text { type }\end{array}$ \\
\hline Pure PES & 18 & 82 & 0 & - \\
M1 & 18 & 81 & 1 & Brij35 \\
M2 & 18 & 79 & 3 & Brij35 \\
M3 & 18 & 77 & 5 & Brij35 \\
M4 & 18 & 75 & 7 & Brij35 \\
M5 & 18 & 72 & 10 & Brij35 \\
\hline M6 & 18 & 81 & 1 & Brij98 \\
M7 & 18 & 79 & 3 & Brij98 \\
M8 & 18 & 77 & 5 & Brij98 \\
M9 & 18 & 75 & 7 & Brij98 \\
M10 & 18 & 72 & 10 & Brij98 \\
\hline M11 & 18 & 81 & 1 & Brij58 \\
M12 & 18 & 79 & 3 & Brij58 \\
M13 & 18 & 77 & 5 & Brij58 \\
M14 & 18 & 75 & 7 & Brij58 \\
M15 & 18 & 72 & 10 & Brij58 \\
\hline
\end{tabular}

\section{Membrane Characterization}

The membrane chemical composition, hydrophilicity and mechanical test were inspected. The presence of Brij chemical groups in the membrane was examined with Fourier Transform Infrared (FTIR) Spectrophotometer (Shimadzu, Japan).

Degree of hydrophilicity of the membrane surface was determined by the water contact angle measurement using a Contact angle meter (Drop Master 300, Kyowa Interface Science Co., Japan).

Membrane strength was evaluated using a material testing machine (Autograph, Shimadzu, Japan). The loading velocity of the instrument was controlled at $20 \mathrm{~mm} / \mathrm{min}$, measurement repeated three times on each membrane and average data used.

\section{Membrane Filtration Performance}

The permeability and solute rejection of prepared membranes were studied by filtration experiment using a dead-end UF cell. The membrane was pressurized at 1 bar for 1 hour filtration of DI water. The generated permeate was weighed and determination of flux of pure water then performed using Equation $(1)^{30}$ :

$J=\frac{\Delta V}{A \times \Delta t}$

$\mathrm{J}$ denotes the water flux $\left(\mathrm{L} / \mathrm{m}^{2} . \mathrm{h}\right), \Delta \mathrm{V}$ is the permeate (L) generated during the filtration time ( $\Delta \mathrm{t}$, hour), and A represents the area of the membrane sample in the UF cell $\left(\mathrm{m}^{2}\right)$. The filtration experiment was also used to evaluate membrane performance on the basis of rejection of humic acid (HA) solution. The concentrations of HA before and after membrane filtration were assayed using UV-VIS Spectrophotometry instrument. With the concentration data, the rejection of HA was calculated using Equation $(2)^{30}$ :

$$
R=\left(1-\frac{C_{p}}{C_{f}}\right) \times 100 \%
$$

$\mathrm{Cf}$ is the initial concentration of humic acid, $\mathrm{Cp}$ is humic acid concentration after membrane filtration, and $\mathrm{R}$ is the rejection percentage of humic acid (\%). 


\section{RESULTS AND DISCUSSION}

Analysis using FTIR spectroscopy is meant to observe the chemical groups in the material. ${ }^{31}$ Figure-1 presents the resulting IR spectra of the pure and Brij-blended PES membranes. The most distinguished structure of PES is denoted by the presence of $\mathrm{SO}_{2}$ at $3096.11 \mathrm{~cm}^{-1}$. The existence of Brij in the membrane system is also evaluated by IR analysis in Fig. 1. In general, modified and original membranes have similar infrared absorption bands as well as the identical basic structure of PES, even after modification with Brij. However, some new infrared absorption bands belonging to specific groups of Brij are observed, for instance, at a wave number range of $2850-3000 \mathrm{~cm}^{-1}$ which specified the $\mathrm{CH}_{3}, \mathrm{CH}_{2}$, and $\mathrm{CH}$ aliphatic compounds. In addition, the band at $3600 \mathrm{~cm}^{-1}$ shows the $-\mathrm{OH}$ group from Brij. Altogether, these results confirm that Brij has been successfully introduced in the membrane. In terms of concentration, no significant change in IR spectra was observed.

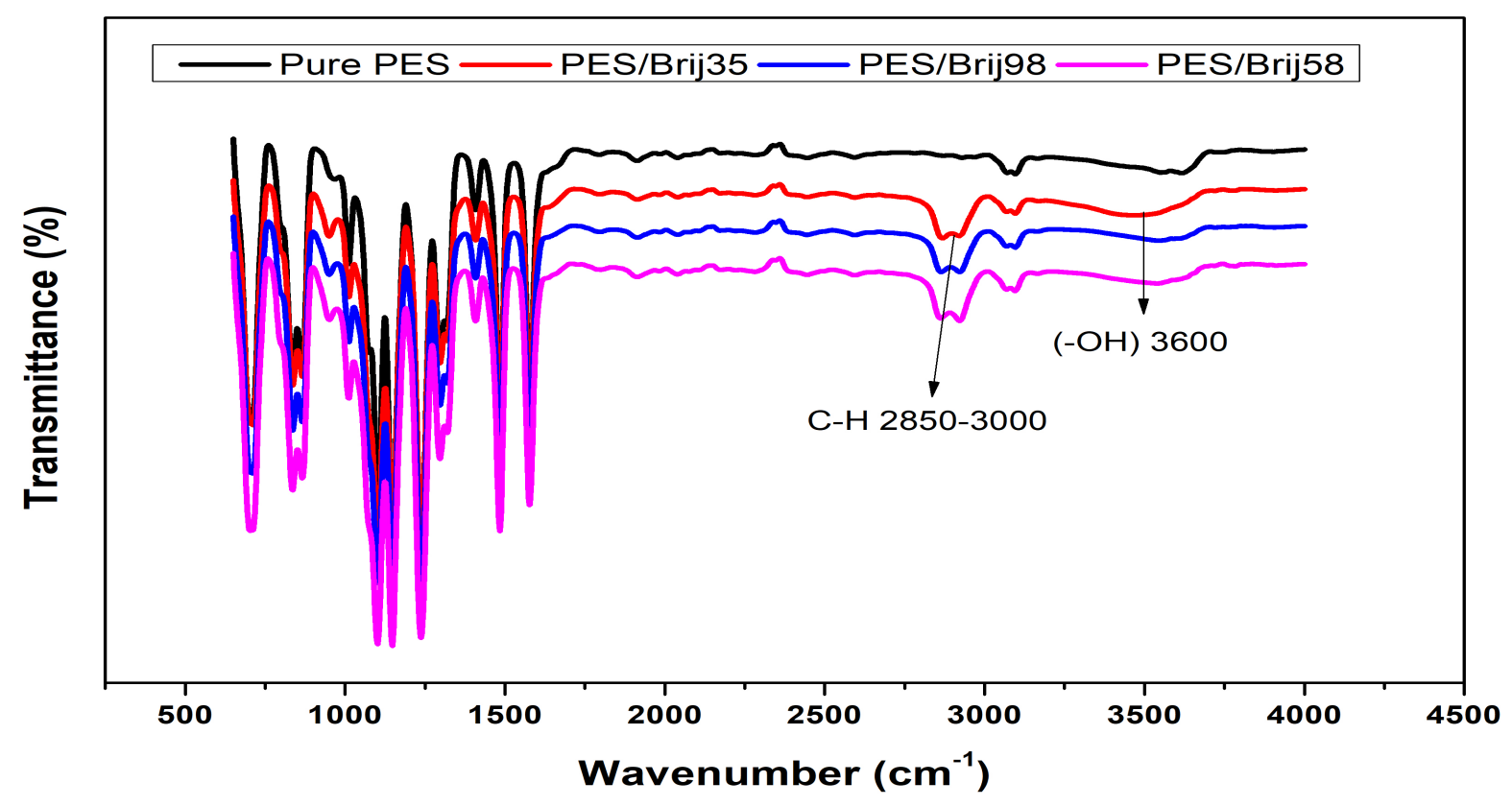

Fig.-1: Infrared Spectra of the Pure and Brij-blended PES Membranes

\section{Surface Hydrophilicity and Porosity}

The degree of membrane hydrophilicity was observed through the measurement of surface water contact angle. The water contact angle is a scale of surface wetness of the membrane observed from the interactivity of water droplet when contacted on the membrane surface. A membrane is categorized as hydrophobic when water is dropped on its surface and does not spread or absorbed well. The droplet usually forms a contact angle of either close to or above $90^{\circ}$. In contrast, membranes with a high degree of hydrophilicity have contact angles below $90^{\circ}$ since the contacted water droplets are well absorbed by the membrane surface. ${ }^{33}$ This means the lower the water contact angle value, the more hydrophilic the membrane.

Figure-2 shows changes in the surface contact angle of membranes after modification with Brij35, Brij58, and Brij98. From these results, the addition of Brij as an additive in membrane formation has proven to increase the hydrophilicity degree of the PES-based membrane. From Fig.-2, the Brij-blended membranes have smaller water contact angles than pristine PES. When compared between three different Mw of Brij, the surface contact angle of Brij35-modified membranes show more pronounced decrease than those modified with Brij58 and Brij 98. This is because Brij-35 is a non-ionic surfactant with an HLB number 16.9. In contrast, the HLB values of Brij-58 and Brij-98 are 16 and 15, respectively. The higher the number, the more hydrophilic the material.

The membrane water contact angle is not only affected by the hydrophilic nature of the material but also by the membrane porous properties. ${ }^{34}$ From Fig. 3, M2 membrane has the highest porosity resulting in the 
RASĀYAN J. Chem.

Vol. 12 | No. 3 |1135 - 1143| July - September | 2019

lowest water contact angle value. The porosity for the M2 membrane is $46.15 \%$ and its water contact angle is $56.6^{\circ}$. The higher porosity of the membrane shows it has more pores on its surface area. A water droplet which plummeted on the membrane with high surface porous is adsorbed faster and easier resulting in the formation of a smaller angle on the membrane surface. ${ }^{10}$ This means the water contact angle of the membrane decreases with increasing porosity.

From Fig.-3, the molecular weights and concentrations of Brij remarkably affecting the surface porosity of fabricated membranes. Generally, the Brij-blended membranes have more pores than that of original PES. This is because blending improves the hydrophilicity of the polymer solution by escalating up the precipitation speed of solvent-nonsolvent during the inversion phase process. Moreover, Brij has a great affinity to water causing its particles to have a higher tendency to be attracted on the top layer of the membrane or even being leached out. ${ }^{22,35,36}$ These phenomena subsequently resulted in a membrane with high surface porosity. The addition of Brij35 produced a membrane with higher average porosity compared to the other two presumably due to its slightly higher hydrophilicity and HLB number.

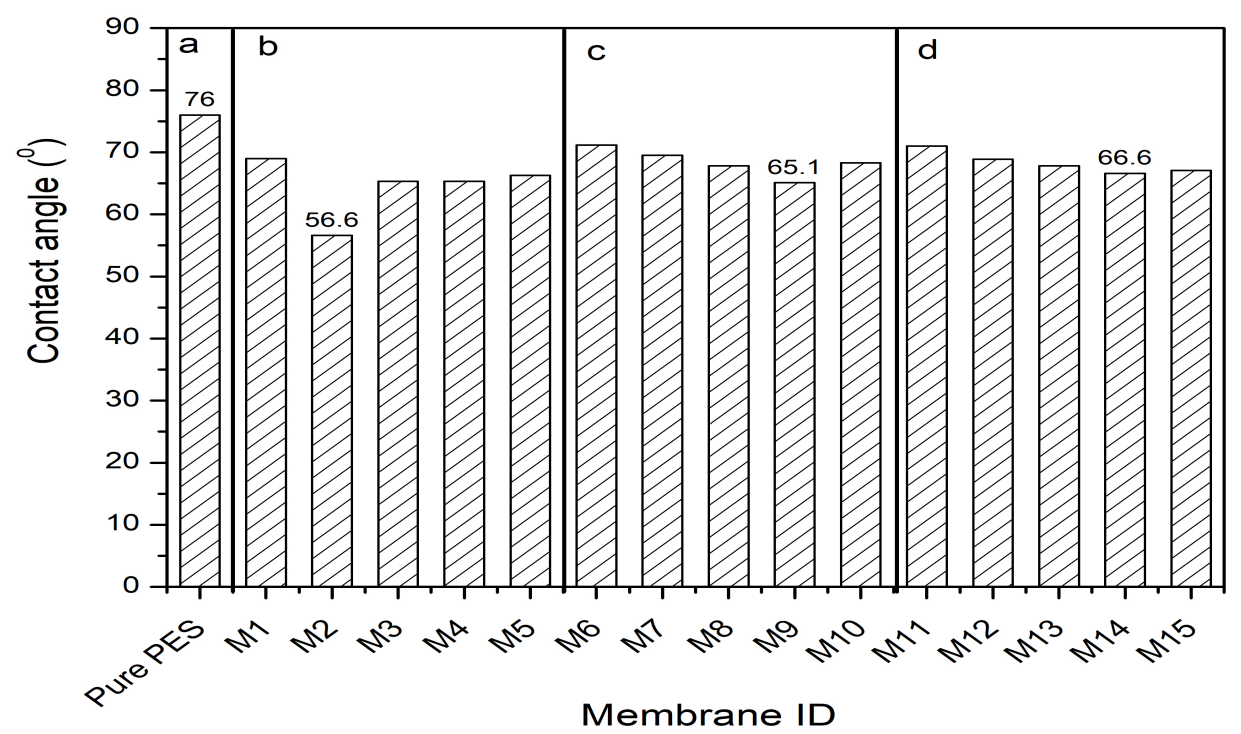

Fig.-2: The Water Contact Angle of Fabricated Membranes (a) Pure PES, (b) Brij35, (c) Brij98, (d) Brij58.

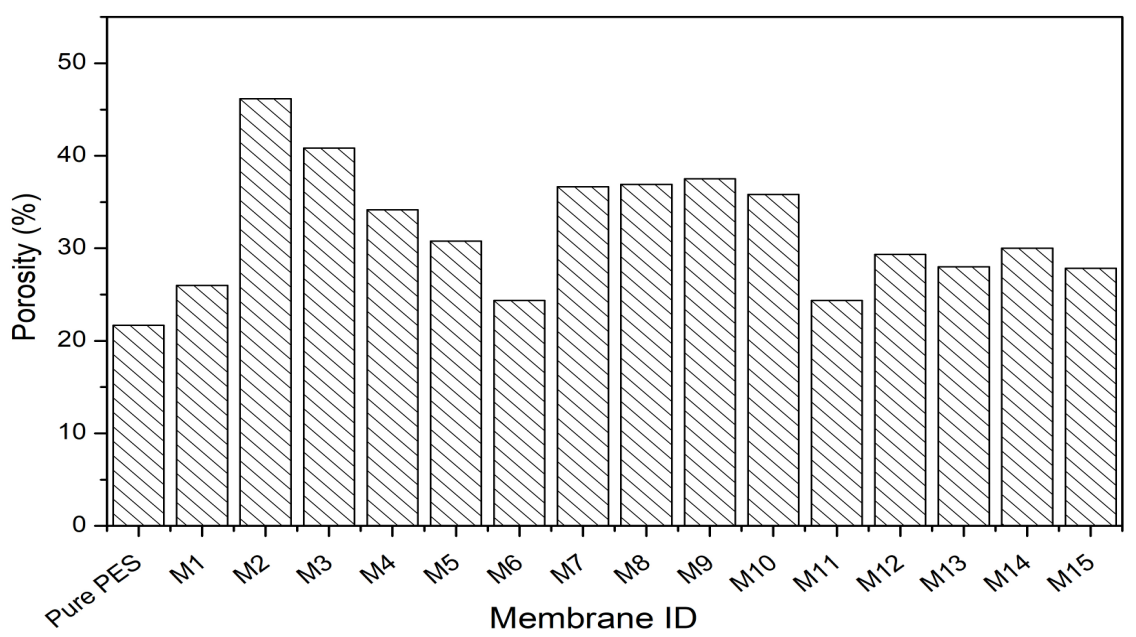

Fig.-3: Surface Porosity of Fabricated Membranes

\section{Pure Water Flux (PWF)}

Some important criteria for determining the performance of membranes include selectivity and pure water permeability. These two strategies related to the amount and size of pores on the upper layer of the membrane. ${ }^{37}$ Performance test of the membrane was carried out by calculating the pure water flux (PWF). 
RASĀYAN J. Chem.

Vol. 12 | No. 3 |1135 - 1143| July - September | 2019

The effects of concentration and molecular weight of Brij which blended in the polymer solution on the PWF is given in Fig.-4.

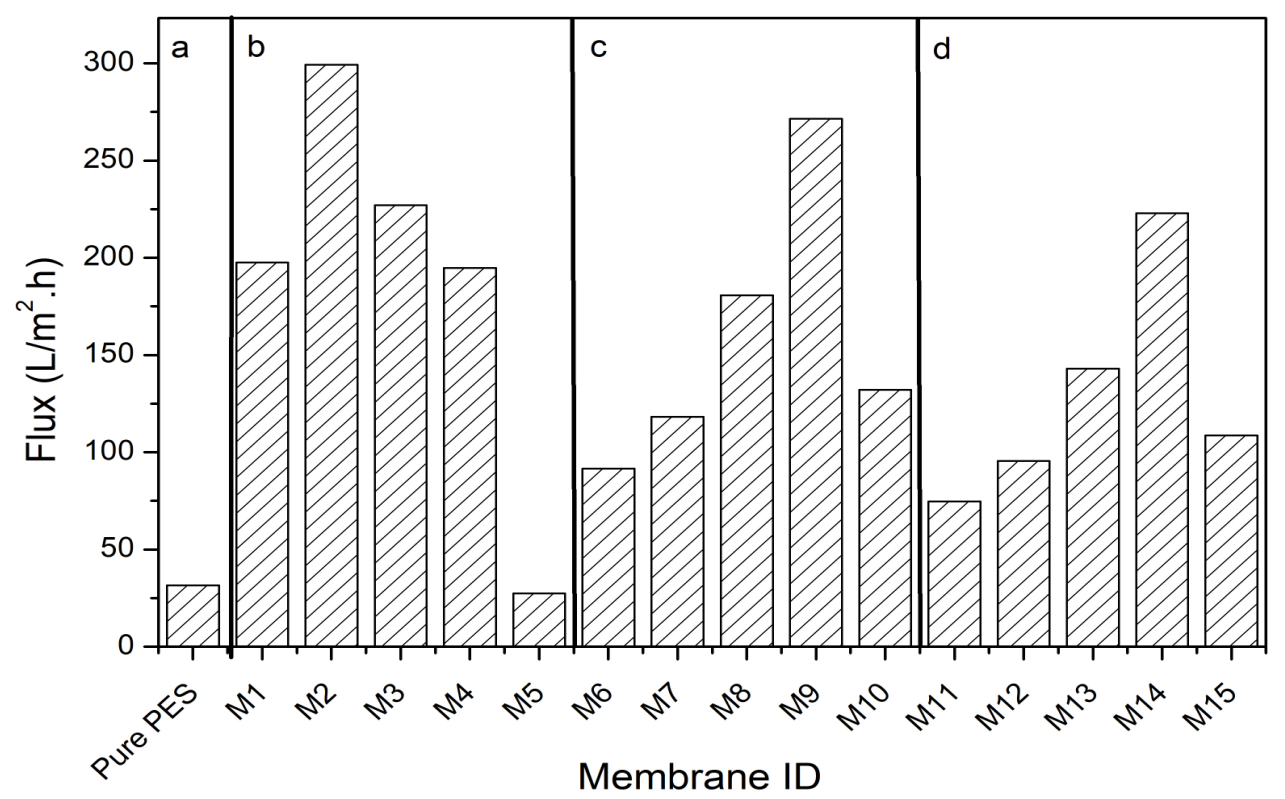

Fig.-4: Pure Water Flux of (a) Pure PES, and those Blended with (b) Brij35, (c) Brij98, (d) Brij58 Membranes

From Fig.-4, it is evident that PWF upsurges by increasing the Mw of Brij. The obtained PWF for the pure membrane is $31.628 \mathrm{~L} / \mathrm{m}^{2} . \mathrm{h}$. With the addition of Brij58 (Mw $\left.1124 \mathrm{~g} / \mathrm{mol}\right)$ of $3 \mathrm{wt} \%$, the PWF is generated higher at $95.4716 \mathrm{~L} / \mathrm{m}^{2} . \mathrm{h}$ and increased incredibly to $299.289 \mathrm{~L} / \mathrm{m}^{2} . \mathrm{h}$ when Brij35 (Mw $1199,558 \mathrm{~g} / \mathrm{mol}$ ) was added with the same concentration. The improved results are attributed to Brij which functions as pore formation agent resulting in increased porosity on the membrane upper surface. The rapid diffusion process between solvents and non-solvents resulted in the increase of polymer fraction at the top layer of the membrane. The formation of the top layer is caused by spinodal demixing from the casting solution. Brij with a lower molecular weight is easily transported by the solvent and hindering the formation of porous structure during the membrane formation. ${ }^{31,38}$

For the varying concentrations, it is observed that, for Brij with higher molecular weight, the concentration required to produce the highest water flux is smaller and may be seen on the membrane with the addition of Brij58 (Mw $1124 \mathrm{~g} / \mathrm{mol}$ ) and Brij98 (Mw $1149.56 \mathrm{~g} / \mathrm{mol}$ ). The highest PWF value was obtained from the addition of Brij at $7 \mathrm{wt} \%$. On the membrane with the addition of Brij35 (Mw $1199,558 \mathrm{~g} / \mathrm{mol}$ ), the highest PWF was found at Brij concentration of $3 \mathrm{wt} \%$. In this study, the optimum concentration of Brij-35, Brij98, and Brij58 was found at 3, 7 and 7 wt. \%, respectively. These results are mainly related to the viscosity of the polymer solution. During the membrane formation, the polymerpoor phase forms pores and polymer-rich phase forms the matrix structure of the membrane. In membrane without Brij blending, the polymer-poor phase is lesser in the surface, and therefore product with lower porosity is formed, and subsequently causes a decrease in water flux. Addition of Brij at higher concentration increase the ratio of the poor-polymer phase to the surface layer and thus a membrane with higher pore formation and water flux is formed. This occurs because the deposition process of PES in the sub-layer becomes faster due to the hydrophilicity properties of Brij. ${ }^{39}$

\section{Humic Acid Rejection}

Membrane performance testing was performed using Humic Acid (HA) as an artificial sample to determine membrane performance in removing natural organic components from water. Natural Organic Matter (NOM) is an organic substance mainly consisting of protein, fat, nutrients and many others. It is one of the most important causes of fouling in membranes applying it for water treatment. ${ }^{40}$ 
RASĀYAN J. Chem.

Vol. 12 | No. 3 |1135 - 1143| July - September | 2019

Figure-5 shows the effects of Brij molecular weights and concentrations on the solute rejection of PESbased membranes. In general, increasing either Brij molecular weight or concentration bring about the decline in humic acid rejection due to the improved pore properties of the membrane after modification with Brij. As shown earlier in Fig.-4, the increment of PWF is observed in the membrane which blended with a higher molecular weight of Brij at an identical concentration. The enhanced pore characteristic of the Brij-blended membrane is further confirmed by the decline in HA rejection which is due to the formation of macrovoid in the membrane caused by Brij particles.

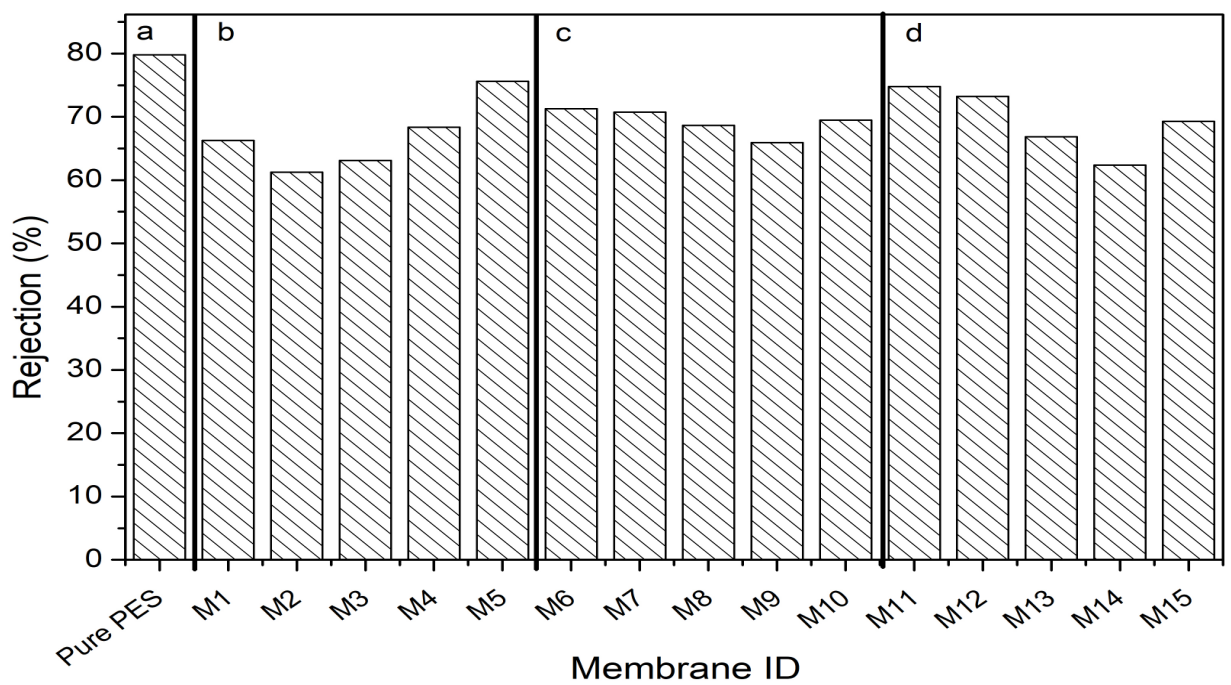

Fig.-5: Humic Acid Rejection of Fabricated Membranes; (a) Pure PES, and with Addition of (b) Brij35, (c) Brij98, (d) Brij58

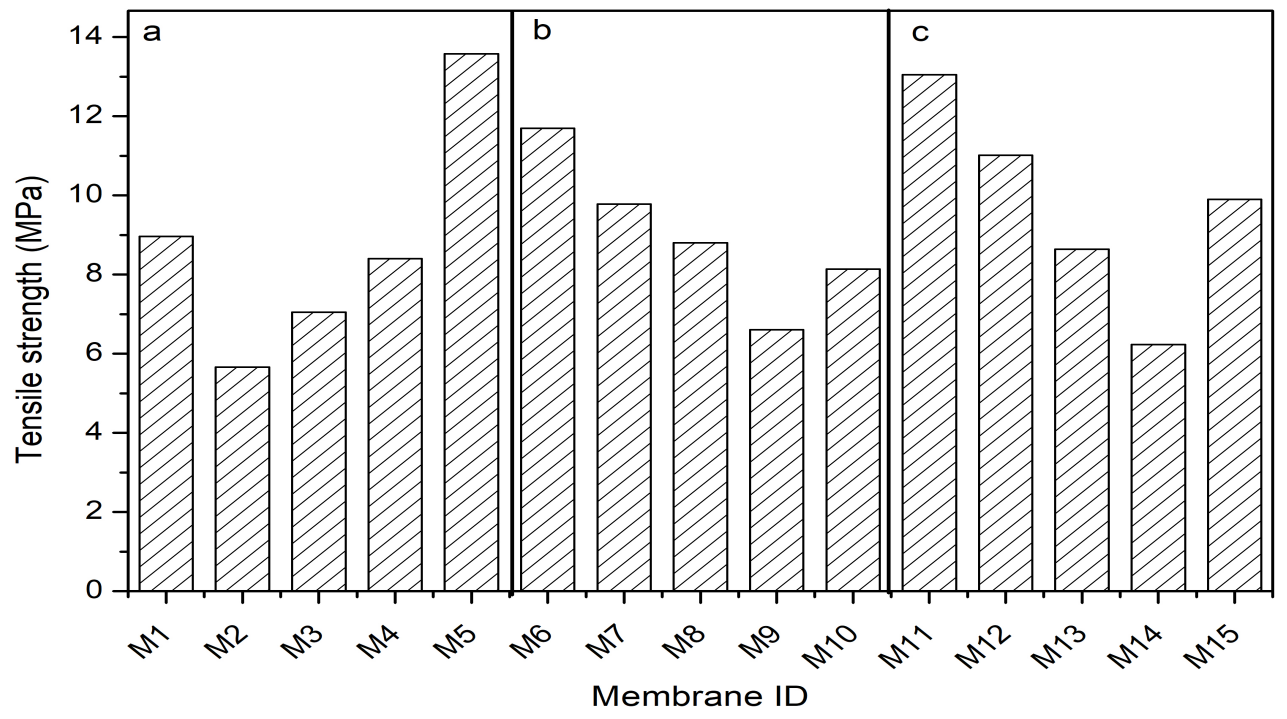

Fig.-6: Tensile Strength of PES Membranes with the Addition of; (a) Brij35, (b) Brij98, (c) Brij58.

\section{Mechanical Properties}

Tensile and elongation at break are the most common parameters used to evaluate the mechanical trait of the membrane. The measurement results of those two parameters for fabricated membranes with and without the addition of Brij of different concentrations and molecular weights are shown in Fig. 6. Higher Brij concentration results in the reduction of tensile strength. For instance, tensile strength decreases from 8.96 MPa to 5.66 MPa in membrane with the addition of Brij35 at concentration of $3 \mathrm{wt} . \%$. This is because the porosity of the membrane increases with the rising concentration of Brij35. Selection of the right Brij molecular weight reduces the formation of macrovoid and as a result increases the tensile 
strength of the membrane produced. However, when its molecular weight is too high, the porosity of the membrane increases and thus decreases the tensile strength.

It is correct to conclude that changes in the membrane's mechanical properties are mainly caused by variations in its structure. The variations are brought about by changes in the concentration or molecular weight of the Brij. To achieve a membrane with decent mechanical traits, the concentration and Mw of the Brij must be considered.

\section{CONCLUSION}

In this research, the effects of different concentrations of Brij on the performance of the PES-based membrane were studied. The addition of Brij produced a membrane with better permeation performance than original PES due to enhanced hydrophilicity and pore properties. Among the three types of Brij, Brij35 showcased overall excellent performances most probably due to slightly higher particle size and HLB number. The optimum concentration was found different for each molecular weight. The best concentration for Brij35 loading was $3 \mathrm{wt} . \%$ and $7 \mathrm{wt} . \%$ for both Brij98 and Brij58. This is attributed to the larger molecular weight of Brij35 compared to the other two. Therefore, a lesser concentration is needed to fabricate a membrane with desirable characteristic and performance.

\section{ACKNOWLEDGMENT}

We express fully gratitude to the Ministry of Research, Technology, and Higher Education of the Republic of Indonesia under "PMDSU" program for financial support of this study.

\section{REFERENCES}

1. H. Yu, X. Zhang, Y. Zhang, J. Liu, and H. Zhang. Desalination, 326, 69(2013), DOI:10.1016/j.desal.2013.07.018.

2. A. Basile and F. Gallucci, Membranes for Membrane Reactors: Preparation, Optimization and Selection. United Kingdom: John Wiley and Sons, (2011).

3. S. Pourjafar, A. Rahimpour, and M. Jahanshahi. J. Ind. Eng. Chem., 18, 1398(2012), DOI: 10.1016/j.jiec.2012.01.041.

4. S. Mulyati, M. . Armando, H. Mawardi, A. Fahrina, N. Malahayati, and Syawaliah. Rasayan J. Chem., 11, 1609(2018), DOI: 10.31788/RJC.2018.1144047

5. N. Kusumawati, P. Setiarso, and S. Muslim. Rasayan J. Chem., 11, 1034(2018), DOI: 10.31788/RJC.2018.1133020.

6. S. E. Cahyaningrum, N. Herdyastuti, A. Firdausa, and D. Yanrita. Rasayan J. Chem., 10, 959(2017), DOI: $10.7324 /$ RJC.2017.1031635.

7. I. Gustian, Asdim, E. Maryanti. Rasayan J. Chem., 9, 608(2016).

8. N. Arahman, T. Maimun, and M. R. Bilad, J. Geomate, 15, 50, (2018), DOI: 10.21660/2018.50.95424.

9. M. Y. Wahab, S. Muchtar, S. Jeon, L. Fang, S. Rajabzadeh, R. Takagi, N. Arahman, S. Mulyati, M. Riza, H. Matsuyama. J. Appl. Polym. Sci., 0, 47737, (2019), DOI: 10.1002/app.47737.

10. S. Muchtar, M. Y. Wahab, S. Mulyati, N. Arahman, and M. Riza. J. Water Process Eng., 28, 293(2019), DOI: 10.1016/j.jwpe.2019.02.012.

11. S. Muchtar, M. Y. Wahab, L. Fang, S. Jeon, S. Rajabzadeh, R. Takagi, N. Arahman, S. Mulyati, M. Riza, H. Matsuyama. J. Appl. Polym. Sci., 136, 47312, (2019), DOI: 10.1002/app.47312.

12. C. Zhao, J. Xue, F. Ran, and S. Sun. Prog. Mater. Sci., 58, 76(2013), DOI: 10.1016/j.pmatsci.2012.07.002.

13. N. Nasrollahi, S. Aber, V. Vatanpour, and N. M. Mahmoodi. Mater. Chem. Phys., 222, 338(2019), DOI: 10.1016/j.matchemphys.2018.10.032.

14. S. Ayyaru and Y.-H. Ahn. J. Ind. Eng. Chem., 67, 199(2018), DOI: 10.1016/j.jiec.2018.06.030.

15. N. E. Salim, N. A. M. Nor, J. Jaafar, A. F. Ismail, M. R. Qtaishat, T.Matsuura, M. H. D. Othman, M. A. Rahman, F. Aziz, N. Yuso,. Appl. Surf. Sci., 465, 180(2019), DOI: 10.1016/j.apsusc.2018.09.161.

16. N. Arahman, T. Maimun, Mukramah, and Syawaliah, AIP Conf. Proc., 1788, 030018 (1-7), (2017), DOI: $10.1063 / 1.4968271$.

17. N. Ghaemi, S. S. Madaeni, A. Alizadeh, P. Daraei, V. Vatanpour, and M. Falsa, Desalination, 290, 1142 
RASĀYAN J. Chem.

Vol. 12 | No. 3 |1135 - 1143| July - September | 2019

99(2012), DOI: 10.1016/j.desal.2012.01.013.

18. S. Saedi, S. S. Madaeni, A. Arabi Shamsabadi, and F. Mottaghi. Sep. Purif. Technol., 99, 104(2012), DOI: $10.1016 /$ j.seppur.2012.08.028.

19. P. Zhang, H. Yang, and Z. Xu. Ind. Eng. Chem. Res., 51, 4388(2012), DOI: 10.1021/ie201806v.

20. M. Amirilargani, E. Saljoughi, and T. Mohammadi. Desalination, 249, 837(2009), DOI: http://dx.doi.org/10.1016/j.desal.2009.01.041.

21. N. Ghaemi, S. S. Madaeni, A. Alizadeh, P. Daraei, and A. Akbar. Sep. Purif. Technol., 85, 147(2012), DOI: $10.1016 / j . s e p p u r .2011 .10 .003$.

22. A. Jijnssonl and B. Jijnsson. J. Memb. Sci., 56, 49(1991), DOI: 10.1016/0376-7388(91)85015-W.

23. M. Omidvar, S. Mousavi, M. Soltanieh, and A. A. Safekordi. J. Environ. Heal. Sci. Eng., 12, 1(2014)

24. M. Omidvar, M. Soltanieh, S. M. Mousavi, E. Saljoughi, A. Moarefian, and H. Saffaran. J. Environ. Heal. Sci. Eng., 13, 42(2015), DOI: 10.1186/s40201-015-0201-3.

25. Mukramah, Syawaliah, Sri Mulyati, and Nasrul Arahman. IOP Conf. Ser. Mater. Sci. Eng., 180, 1(2017), DOI: 10.1088/1742-6596/755/1/011001.

26. M. Y. Wahab, S. Muchtar, S. Jeon, L. Fang, S. Rajabzadeh, R. Takagi, N. Arahman, S. Mulyati, M. Riza, H. Matsuyama. J. Appl. Polym. Sci., 47737, 1(2019), DOI: 10.1002/app.47737

27. . Kim and K. Lee. J. Memb. Sci., 230, 183(2004), DOI: 10.1016/j.memsci.2003.11.002.

28. S. Muchtar, N. Arahman, Mukramah, and S. Mulyati. IOP Conf. Ser. Mater. Sci. Eng., 180, 1(2017), DOI: $10.1088 / 1757-899 X / 180 / 1 / 012129$.

29. E. Saljoughi, M. Amirilargani, and T. Mohammadi. Desalination, 262, 72(2010), DOI: 10.1016/j.desal.2010.05.046.

30. M. Mulder, Basic Principles of Membrane Technology. Netherlands: Kluwer Academic Publishers, 4th ed.; (1991).

31. A. Moarefian, H. A. Golestani, and H. Bahmanpour. J. Environ. Heal. Sci. Eng., 12, 1(2014)

32. D. . Pavia, G. . Lampman, and G. . Kriz, "Peak Interpretation Lists," in Introduction to Spectroscopy: A Guide for Students of Organic Chemistry, pp. 174-177, (1979).

33. J. H. Jhaveri and Z. V. P. Murthy. Desalination, 379, 137(2016), DOI: 10.1016/j.desal.2015.11.009.

34. J. Jiang, L. Zhu, L. Zhu, B. Zhu, and Y. Xu. Langmuir, 27, 14180(2011), DOI: 10.1021/la202877k.

35. H. Wu, Y. Liu, L. Mao, C. Jiang, J. Ang, and X. Lu. J. Memb. Sci., 532, 20(2017), DOI: 10.1016/j.memsci.2017.03.010.

36. H. Wu, B. Tang, and P. Wu. J. Memb. Sci., 451, 94(2014), DOI: 10.1016/j.memsci.2013.09.018.

37. M.-J. Han and S.-T. Nam. J. Memb. Sci., 202, 55(2002), DOI: 10.1016/S0376-7388(01)00718-9.

38. K. Kimmerle and H. Strathmann. Desalination, 79, 283(1990), DOI:10.1016/0011-9164(90)85012Y.

39. H. Strathmann, K. Kock, P. Amar, and R. W. Baker. Desalination, 16, 179(1975), DOI: 10.1016/S0011-9164(00)82092-5.

40. R. Singh and M. K. Purkait. J. Water Process Eng., 14, 9(2016), DOI: 10.1016/j.jwpe.2016.10.001.

[RJC-5340/2019] 